\title{
Occurrence of fungal diseases on blue lupine (Lupinus angustifolius L.) plants at different regions of Poland
}

\section{Występowanie chorób grzybowych na roślinach łubinu wąskolistnego (Lupinus angustifolius L.) w różnych rejonach Polski}

\author{
Janusz Podleśny ${ }^{1 *}$, Anna Podleśna ${ }^{1}$, Tadeusz Bieniaszewski ${ }^{2}$
}

\begin{abstract}
Summary
The aim of the study was to evaluate the degree of blue lupine (Lupinus angustifolius L.) infestation by pathogenic fungi, in particular regions of Poland, in dependence on cultivar and course of weather conditions. An experiment was conducted at the Stations of Research Centre for Cultivar Testing located in the following provinces: zachodniopomorskie, wielkopolskie, lubelskie, kujawsko-pomorskie, mazowieckie, podlaskie, podkarpackie, warmińsko-mazurskie and pomorskie. Sixteen cultivars of blue lupine with different resistance to pathogenic fungi were included in this study. It was found that the occurrence of fungal diseases on blue lupine plants varied in particular regions of Poland. Root rot (Fusarium oxysporum, Rhizoctonia solani and others) and white mould (Sclerotinia sclerotiorum) occurred at the highest severity while wilting of lupine (F. oxysporum) and particularly seed borne anthracnose (Colletotrichum ssp.) appeared at considerably lower intensity. It has been proved that there is a clear dependence between fungal disease development and course of weather conditions as well as between infestation of plants by pathogenic fungi and collected yield. Among analyzed pathogens Colletotrichum ssp. and Fusarium oxysporum had the greatest impact on the blue lupine yield.
\end{abstract}

Key words: blue lupine; cultivar; pathogens; regions of Poland; yield

\section{Streszczenie}

Celem badań była ocena stopnia porażenia roślin łubinu wąskolistnego (Lupinus angustifolius L.) przez grzyby chorobotwórcze, w poszczególnych rejonach Polski, w zależności od uprawianej odmiany oraz przebiegu warunków pogodowych. Doświadczenie prowadzono w Stacjach Oceny Odmian Centralnego Ośrodka Badania Odmian Roślin Uprawnych (COBORU), zlokalizowanych w następujących województwach: zachodniopomorskie, wielkopolskie, lubelskie, kujawsko-pomorskie, mazowieckie, podlaskie, podkarpackie, warmińsko-mazurskie i pomorskie. W badaniach uwzględniono 16 odmian łubinu wąskolistnego, które jak wykazano, charakteryzowała zróżnicowana odporność na poszczególne grzyby chorobotwórcze. Stwierdzono zróżnicowane występowanie chorób na roślinach łubinu wąskolistnego w poszczególnych rejonach Polski. W największym nasileniu występowały zgorzel siewek i zgnilizna twardzikowa, natomiast w znacznie mniejszym - fuzaryjne więdnięcie łubinu, a zwłaszcza antraknoza. Stwierdzono wyraźną zależność między rozwojem chorób a przebiegiem warunków pogodowych oraz między porażeniem roślin przez grzyby chorobotwórcze a ich plonowaniem. Spośród analizowanych patogenów największy wpływ na poziom plonowania łubinu miały Colletotrichum ssp. i Fusarium oxysporum.

Słowa kluczowe: łubin wąskolistny; odmiana; patogeny; regiony Polski; plon

\footnotetext{
Instytut Uprawy Nawożenia i Gleboznawstwa - Państwowy Instytut Badawczy

Czartoryskich 8, 24-100 Puławy

${ }^{2}$ Uniwersytet Warmińsko-Mazurski w Olsztynie

Słoneczna 46A, 10-710 Olsztyn

*corresponding author: jp@iung.pulawy.pl
} 


\section{Wstęp / Introduction}

W 2010 roku zostały wprowadzone w Polsce dopłaty do uprawy roślin strączkowych, co spowodowało wzrost zainteresowania rolników tą grupą roślin (Jerzak 2014). W szczególności odnosi się to do areału łubinu wąskolistnego i żółtego. W związku z wysoką ceną nawozów azotowych, rolnicy coraz częściej postrzegają rośliny strączkowe jako dodatkowe źródło azotu (Szukała 2012). Dzięki zdolności do wiązania $\mathrm{N}_{2}$ łubin nie wymaga nawożenia tym składnikiem (Kalembasa i wsp. 2014), a nawet pozostawia znaczną jego część dla rośliny następczej (Buraczyńska i Ceglarek 2008; Prusiński i wsp. 2008).

Stosunkowo niskie, a przede wszystkim zmienne w latach plony nasion (Kopiński i Matyka 2012), stanowią znaczną przeszkodę $\mathrm{w}$ powiększaniu powierzchni uprawy tej grupy roślin. Wynika to $\mathrm{w}$ dużej mierze $\mathrm{z}$ okresowego niedoboru wody w glebie (Podleśna i wsp. 2014) oraz porażenia roślin przez patogeny (Prusiński 2010). Szczególnie niebezpieczną chorobą dla łubinu jest antraknoza (Filoda i wsp. 2001; Thomas i Sweetingham 2004), która bardzo szybko rozprzestrzenia się $\mathrm{w}$ łanie i często powoduje zniszczenie całej plantacji. Rozwój i przebieg tej choroby w bardzo dużym stopniu zależy od jakości materiału siewnego, zwłaszcza braku jego zasiedlenia przez grzyby chorobotwórcze (Kurowski i Jaźwińska 2010) oraz przebiegu warunków pogodowych (Horoszkiewicz-Janka i wsp. 2011). Bardzo ważne jest wykonywanie analiz na obecność tych patogenów oraz częsty monitoring stanu plantacji. W związku z małą liczbą środków chemicznych przewidzianych do zwalczania chorób łubinu (obecnie zarejestrowany jest preparat Gwarant $500 \mathrm{SC}-$ s.cz. chlorotalonil do zwalczania antraknozy i zaprawa nasiennaVitavax 200 FS - s.cz. tiuram i karboksyna stosowana przeciwko zgorzeli siewek) bardzo ważnym zagadnieniem staje się poszukiwanie odmian łubinu o zwiększonej odporności na grzyby chorobotwórcze. Łubin wąskolistny uważany jest powszechnie za gatunek o większej odporności na antraknozę niż pozostałe gatunki łubinu (Horoszkiewicz-Janka i wsp. 2011), ale brakuje badań nad odpornością poszczególnych odmian na tę chorobę. Warunki klimatyczne Polski są zróżnicowane, co daje możliwość przeprowadzenia takiej analizy. Badania te być może pozwolą także na dobór wybranych odmian łubinu wąskolistnego do poszczególnych rejonów uprawy.

Celem badań była ocena stopnia porażenia roślin łubinu wąskolistnego przez patogeny w zależności od odmiany oraz przebiegu warunków pogodowych w poszczególnych rejonach Polski.

\section{Materiały i metody / Materials and methods}

Doświadczenia prowadzono w latach 2010-2012, w Stacjach Oceny Odmian Centralnego Ośrodka Badania Odmian Roślin Uprawnych (COBORU), w następujących województwach i miejscowościach: zachodniopomorskie (Białogard i Rarwino), wielkopolskie (Bobrowniki i Kościelec), lubelskie (Cicibór Duży), kujawsko-pomorskie (Głodowo), mazowieckie (Kawęczyn), podlaskie (Marianowo), podkarpackie (Nowy Lubliniec), warmińsko-ma- zurskie (Ruska Wieś i Wrócikowo) i pomorskie (Wyczechy) (rys. 1), w układzie losowanych bloków, w 4 powtórzeniach. W badaniach uwzględniono następujące odmiany łubinu wąskolistnego: Baron, Bojar, Boruta, Dalbor, Graf, Heros, Kadryl, Kalif, Karo, Mirela, Neptun, Oskar, Regent, Sonet, Tango i Zeus. Odmiany te były nowo wpisanymi na Listę Odmian Roślin Rolniczych oraz wchodziły w skład wzorca służącego do oceny odmian w badaniach COBORU.

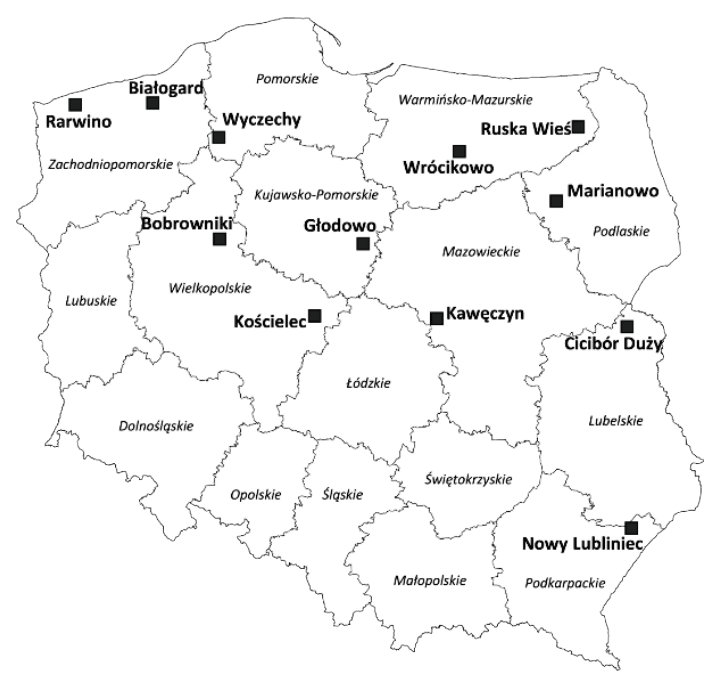

Rys. 1. Lokalizacja doświadczeń $\mathrm{z}$ łubinem wąskolistnym

Fig. 1. Location of experiments with blue lupine

Zakładana obsada roślin wynosiła dla odmian: Mirela, Karo, Baron, Zeus, Graf, Kalif, Bojar, Neptun, Dalbor, Heros i Kadryl - 100 roślin $/ \mathrm{m}^{2}$, dla odmian Boruta i Regent - 120 roślin $/ \mathrm{m}^{2}$, a dla odmiany Sonet $-130 \mathrm{roślin} / \mathrm{m}^{2}$.

Łubin wąskolistny uprawiano najczęściej na glebach należących do kompleksu glebowego żytniego bardzo dobrego lub dobrego. Siew wykonano w końcu marca lub na początku kwietnia. Przedplonem dla łubinu wąskolistnego były zboża, najczęściej jęczmień jary lub pszenica jara. Nawożenie azotem nie było stosowane, natomiast wielkość dawek fosforu i potasu ustalono na podstawie wyników analizy gleby. Przeciętne nawożenie wynosiło w kg/ha: $\mathrm{P}_{2} \mathrm{O}_{5}-40$ i $\mathrm{K}_{2} \mathrm{O}-70$. W okresie wegetacji prowadzono szczegółowe obserwacje podatności odmian łubinu wąskolistnego na choroby. W początkowej fazie wzrostu łubinu (BBCH 12) określono porażenie roślin przez Fusarium ssp., w okresie kwitnienia (BBCH 60) Colletotrichum ssp. i Fusarium oxysporum, w fazie zielonego strąka (BBCH 75) - Sclerotinia sclerotiorum, a na początku dojrzewania (BBCH 80) - Pleospora herbarum poprzez ustalenie liczby roślin zdrowych oraz uszkodzonych przez patogeny. Ocenę zdrowotności łubinu wykonano na 25 roślinach z każdego poletka. Za porażenie roślin przyjęto stosunek liczby roślin porażonych do łącznej liczby roślin wyrażony w \%.

Przebieg warunków pogodowych scharakteryzowano na podstawie ilości opadów i średniej dobowej temperatury powietrza (tab. 1). Powierzchnia poletek do zbioru wynosiła $16 \mathrm{~m}^{2}$. Po zbiorze określono plon nasion łubinu uzyskany w poszczególnych miejscowościach. 
Zwalczanie chwastów dwuliściennych prowadzono metodą chemiczną stosując Afalon Dyspersyjny $450 \mathrm{SC}$ (s.cz. linuron) $\mathrm{w}$ dawce $1,5-2,0 \mathrm{l} / \mathrm{ha}$ lub Linurex $500 \mathrm{SC}$ (s.cz. linuron) $\mathrm{w}$ dawce 1,0-1,5 1/ha. Chwasty jednoliścienne zwalczano stosując preparat Fusilade Super 125 EC (s.cz. fluazyfop-P-butylowy) w dawce 2,5 1/ha. Przeciw szkodnikom stosowano Karate Zeon 050 CS (s.cz. lambdacyhalotryna) w dawce $0,15 \mathrm{l} / \mathrm{ha}$ lub Decis 2,5 EC (s.cz. deltametryna) $\mathrm{w}$ dawce $0,3 \mathrm{l} / \mathrm{ha}$.

Wyniki opracowano statystycznie wykorzystując program STATISTICA v. 10.0. Istotność różnic określano przy użyciu testu Tukeya, przyjmując poziom istotności $\alpha=0,05$.

Przebieg warunków pogodowych w poszczególnych rejonach kraju był bardzo zróżnicowany (tab. 1) i różnie oddziaływał na wzrost, rozwój i plonowanie łubinu. W kwietniu 2010 roku stwierdzono duży niedobór opadów w województwie zachodniopomorskim (Białogard), mazowieckim (Kawęczyn) i warmińsko-mazurskim (Wrócikowo), natomiast w maju odnotowano bardzo dużą ilość opadów w większości rejonów uprawy łubinu, z wyjątkiem miejscowości Białogard, Bobrowniki i Rarwino. Z kolei w czerwcu odnotowano duży niedobór opadów w województwie wielkopolskim (Bobrowniki) i zachodniopomorskim (Rarwino), a dużą ich ilość w województwie warmińsko-mazurskim (Ruska Wieś). W okresie od kwietnia do czerwca 2011 roku odnotowano niedobór opadów prawie we wszystkich województwach. Natomiast w lipcu, w wielu województwach, wystąpił znaczny ich nadmiar. W miesiącach wiosennych 2012 roku zaobserwowano deficyt opadów, który był odczuwalny zwłaszcza w kwietniu (województwo wielkopolskie: Bobrowniki i Kościelec) oraz maju (województwo zachodniopomorskie: Rarwino i Białogard oraz kujawsko-pomorskie: Głodowo). Przeciętna dla wszystkich miejscowości temperatura dobowa w okresie kwiecień-lipiec była podobna we wszystkich latach i wynosiła $w$ granicach $14,6-15^{\circ} \mathrm{C}$. Stwierdzono natomiast większe zróżnicowanie średnich temperatur dobowych pomiędzy miejscowościami. W roku 2010 najwyższą średnią temperaturę dobową w kwietniu odnotowano $\mathrm{w}$ województwie wielkopolskim (Kościelec), w maju w województwie podkarpackim (Nowy Lubliniec) oraz w czerwcu i lipcu w województwach lubelskim (Cicibór Duży) i wielkopolskim (Kościelec). W 2011 roku najwyższą średnią temperaturę dobową w kwietniu, maju, czerwcu i lipcu stwierdzono w województwie wielkopolskim (Bobrowniki i Kościelec). W roku 2012 najwyższą temperaturę $\mathrm{w}$ maju odnotowano $\mathrm{w}$ województwach kujawsko-pomorskim (Głodowo) i mazowieckim (Kawęczyn), w czerwcu w województwie wielkopolskim (Kościelec), a w lipcu w województwach lubelskim (Cicibór Duży) i podkarpackim (Nowy Lubliniec).

Tabela 1. Miesięczna suma opadów oraz średnie temperatury dobowe dla poszczególnych miejscowości (2010-2012)

Table 1. Monthly sum of precipitation and mean day temperatures for individual locations (2010-2012)

\begin{tabular}{|c|c|c|c|c|c|c|c|c|}
\hline \multirow{2}{*}{$\begin{array}{l}\text { Miejscowość } \\
\text { Location }\end{array}$} & \multicolumn{4}{|c|}{$\begin{array}{c}\text { Opady - Precipitation } \\
{[\mathrm{mm}]}\end{array}$} & \multicolumn{4}{|c|}{$\begin{array}{c}\text { Temperatura - Temperature } \\
{\left[{ }^{\circ} \mathrm{C}\right]}\end{array}$} \\
\hline & IV & $\mathrm{V}$ & VI & VII & IV & $\mathrm{V}$ & VI & VII \\
\hline 1 & 2 & 3 & 4 & 5 & 6 & 7 & 8 & 9 \\
\hline \multicolumn{9}{|c|}{2010} \\
\hline Białogard & 11,7 & 95,6 & 78,3 & 114,7 & 7,3 & 10,1 & 15,6 & 20,6 \\
\hline Bobrowniki & 37,3 & 83,1 & 62,5 & 95,6 & 7,9 & 11,2 & 16,5 & 22,5 \\
\hline Cicibór Duży & 23,0 & 126,8 & 97,7 & 48,2 & 8,7 & 12,5 & 19,9 & 22,6 \\
\hline Głodowo & 29,2 & 143,3 & 64,7 & 130,7 & 8,5 & 12,5 & 16,8 & 21,4 \\
\hline Kawęczyn & 15,1 & 155,5 & 77,0 & 67,4 & 9,0 & 13,0 & 17,1 & 20,8 \\
\hline Kościelec & 25,0 & 147,7 & 61,3 & 87,5 & 10,2 & 13,5 & 19,0 & 23,1 \\
\hline Marianowo & 34,8 & 151,8 & 75,5 & 108,1 & 8,3 & 13,4 & 19,9 & 24,1 \\
\hline Nowy Lubliniec & 27,2 & 195,1 & 98,4 & 167,3 & 9,3 & 14,8 & 18,7 & 20,9 \\
\hline Rarwino & 20,0 & 85,1 & 67,7 & 74,8 & 6,5 & 8,7 & 14,1 & 20,0 \\
\hline Ruska Wieś & 42,8 & 140,1 & 75,9 & 94,9 & 7,0 & 12,8 & 16,1 & 20,7 \\
\hline Wrócikowo & 16,9 & 153,0 & 80,8 & 64,1 & 7,3 & 11,9 & 15,8 & 20,5 \\
\hline Wyczechy & 54,3 & 214,6 & 61,2 & 97,6 & 8,7 & 12,4 & 17,1 & 21,0 \\
\hline \multicolumn{9}{|c|}{2011} \\
\hline Białogard & 13,8 & 38,2 & 63,6 & 109,8 & 10,0 & 13,2 & 17,1 & 17,4 \\
\hline Bobrowniki & 5,0 & 32,7 & 65,2 & 152,2 & 11,4 & 14,9 & 19,3 & 19,8 \\
\hline Cicibór Duży & 37,6 & 61,2 & 65,4 & 201,6 & 9,6 & 13,8 & 18,4 & 18,7 \\
\hline Głodowo & 12,4 & 43,4 & 36,2 & 179,3 & 10,4 & 14,2 & 18,2 & 18,1 \\
\hline Kawęczyn & 40,2 & 31,5 & 51,4 & 179,8 & 10,6 & 14,4 & 18,6 & 18,2 \\
\hline Kościelec & 16,5 & 50,2 & 71,6 & 117,0 & 12,3 & 16,4 & 21,0 & 19,9 \\
\hline
\end{tabular}




\begin{tabular}{|c|c|c|c|c|c|c|c|c|}
\hline 1 & 2 & 3 & 4 & 5 & 6 & 7 & 8 & 9 \\
\hline Marianowo & 38,7 & 58,0 & 58,3 & 273,9 & 9,6 & 13,4 & 17,7 & 18,5 \\
\hline Nowy Lubliniec & 52,2 & 31,2 & 86,9 & 201,5 & 10,0 & 14,1 & 17,4 & 19,2 \\
\hline Rarwino & 12,1 & 52,7 & 62,9 & 175,2 & 10,1 & 12,7 & 17,0 & 16,9 \\
\hline Ruska Wieś & 35,7 & 67,1 & 43,9 & 191,6 & 8,7 & 12,6 & 17,1 & 18,4 \\
\hline Wrócikowo & 26,6 & 40,9 & 63,2 & 203,4 & 9,2 & 12,7 & 17,0 & 17,6 \\
\hline Wyczechy & 14,1 & 50,6 & 55,9 & 166,8 & 10,2 & 13,1 & 17,2 & 17,4 \\
\hline \multicolumn{9}{|c|}{2012} \\
\hline Białogard & 31,6 & 24,7 & 104,2 & 102,2 & 8,0 & 13,7 & 15,6 & 18,2 \\
\hline Bobrowniki & 10,0 & 40,4 & 90,8 & 127,5 & 8,6 & 14,8 & 16,5 & 19,0 \\
\hline Cicibór Duży & 37,5 & 55,8 & 126,1 & 27,5 & 8,9 & 14,8 & 16,9 & 21,0 \\
\hline Głodowo & 34,9 & 17,9 & 124,4 & 89,7 & 9,1 & 15,4 & 17,1 & 20,9 \\
\hline Kawęczyn & 46,0 & 46,5 & 67,3 & 74,3 & 9,6 & 15,4 & 17,0 & 20,6 \\
\hline Kościelec & 11,1 & 52,8 & 111,5 & 100,5 & 9,5 & 13,8 & 18,5 & 21,9 \\
\hline Marianowo & 44,6 & 60,3 & 125,5 & 101,1 & 8,5 & 15,1 & 15,5 & 19,7 \\
\hline Nowy Lubliniec & 39,2 & 92,0 & 148,9 & 50,6 & 9,7 & 15,6 & 17,8 & 21,4 \\
\hline Rarwino & 39,8 & 12,8 & 83,0 & 161,1 & 7,1 & 12,5 & 15,1 & 17,3 \\
\hline Ruska Wieś & 64,5 & 65,6 & 99,1 & 126,8 & 7,1 & 13,0 & 13,4 & 18,9 \\
\hline Wrócikowo & 79,5 & 48,5 & 97,6 & 106,0 & 7,8 & 13,3 & 15,1 & 18,9 \\
\hline Wyczechy & 53,8 & 84,3 & 108,3 & 111,7 & 7,9 & 13,8 & 15,0 & 18,4 \\
\hline
\end{tabular}

\section{Wyniki i dyskusja / Results and discussion}

Porażenie roślin przez grzyby chorobotwórcze zależało od lokalizacji doświadczenia i lat badań. We wszystkich latach badań, chociaż nie we wszystkich miejscowościach, stwierdzono występowanie następujących chorób łubinu: antraknozy, zgorzeli siewek, fuzaryjnego więdnięcia łubinu, zgnilizny twardzikowej, opadziny liści łubinu (rys. 2). W największym nasileniu porażały patogeny, które powodują choroby uznawane za mniej groźne w uprawie łubinu wąskolistnego, czyli zgorzel siewek i zgnilizna twardzikowa. Patogeny szczególnie niebezpieczne, takie jak: F. oxysporum, a zwłaszcza Colletotrichum gloeosporioides (Jańczak i wsp. 2001; Podleśny i Brzóska 2010) występowały tylko $\mathrm{w}$ nielicznych miejscowościach. Ponadto obserwowano również niewielkie porażenie roślin przez $P$. herbarum. W latach 2010 i 2012 występowanie antraknozy było większe niż w roku 2011, co spowodowane było większą ilością opadów w okresie kwitnienia łubinu. Jak donoszą Filoda i wsp. (2001), szybkiemu rozprzestrzenianiu się tej choroby sprzyja duża wilgotność i wysoka temperatura powietrza.

W roku 2011 stwierdzono większe, niż w pozostałych latach, nasilenie występowania fuzaryjnego więdnięcia łubinu, co wynikało prawdopodobnie z bardzo dużej ilości opadów i stosunkowo niskiej temperatury w lipcu. Z literatury wynika bowiem, że zarówno za duża, jak i za mała wilgotność powietrza sprzyja rozwojowi fuzariozy (Sowa i Sadowski 1979; Wenda-Piesik i Breza-Boruta 2008).

Zgorzel siewek występowała w każdym roku badań, ale największe jej nasilenie odnotowano w roku 2012. Spowodowane to było większą wilgotnością gleby i niższą temperaturą powietrza po wysiewie nasion niż w latach 2010 i 2011. Uzyskane wyniki znajdują potwierdzenie w badaniach innych autorów (Kurowski i wsp. 2001; Morkunas i wsp. 2011), z których wynika, że w warunkach niesprzyjających kiełkowaniu łubinu zwiększa się porażenie roślin przez patogeny powodujące zgorzel siewek.

Należy uznać, że spektrum chorób, które wystąpiły w prowadzonych badaniach nie było zbyt duże, bowiem według Horoszkiewicz i Filody (2001) łubin wąskolistny może być porażany także przez wiele innych patogenów chorobotwórczych. Najprawdopodobniej, warunki pogodowe występujące w latach badań nie sprzyjały bardzo silnemu rozwojowi chorób grzybowych łubinu.

Pojawianie się chorób było bardzo różne w poszczególnych rejonach kraju (rys. 3). Uwzględniając występowanie wszystkich chorób łącznie stwierdzono, że największy stopień porażenia roślin łubinu przez patogeny miał miejsce w województwach: podkarpackim, pomorskim i warmińsko-mazurskim, znacznie mniejszy w województwach: kujawsko-pomorskim, lubelskim, mazowieckim i podlaskim, a najmniejszy w województwach: wielkopolskim i zachodniopomorskim. Nie oznacza to jednak, że w województwach, w których występowanie chorób było wysokie, również największe było ich oddziaływanie na wzrost, rozwój i plonowanie roślin. Duże znaczenie miała bowiem szkodliwość chorób. Choroby, takie jak: zgorzel siewek, fuzaryjne więdnięcie łubinu, opadzina liści i zgnilizna twardzikowa występowały częściej niż antraknoza, ale ich negatywne oddziaływanie na wzrost i rozwój łubinu było zdecydowanie mniejsze. Największe nasilenie antraknozy stwierdzono w województwach: podkarpackim i podlaskim, zgorzeli siewek i fuzaryjnego więdnięcia łubinu w województwach: kujawsko-pomorskim i mazowieckim, a opadziny liści i zgnilizny twardzikowej w województwach: pomorskim i warmińsko-mazurskim. 


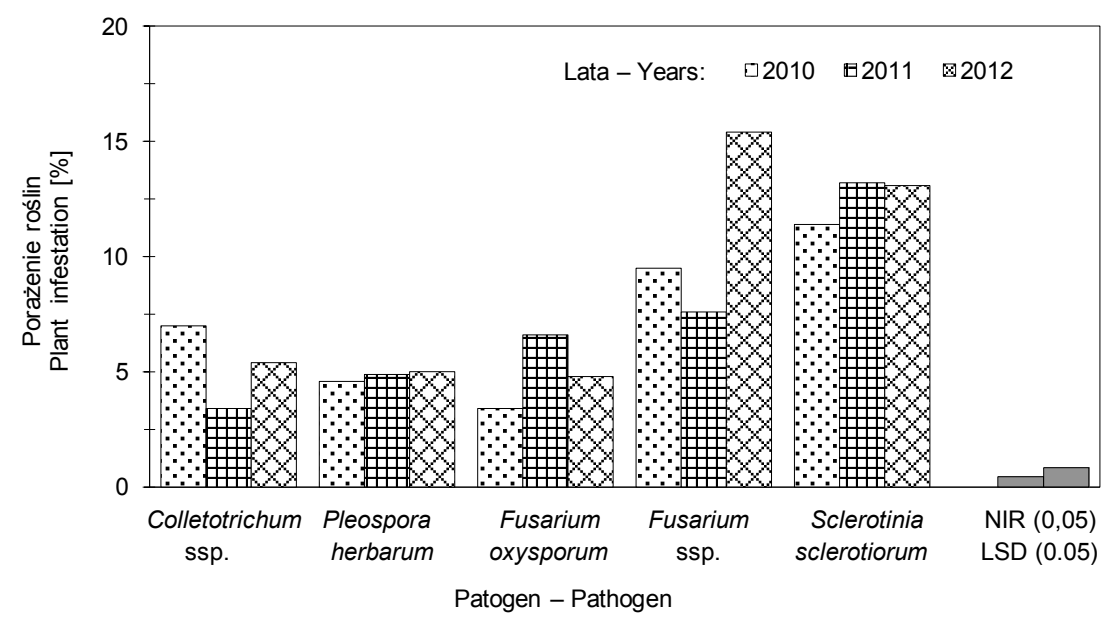

Rys. 2. Porażenie roślin łubinu przez patogeny (średnia dla wszystkich miejscowości)

Fig. 2. Infection of lupine plants by fungal pathogens (mean for all locations)

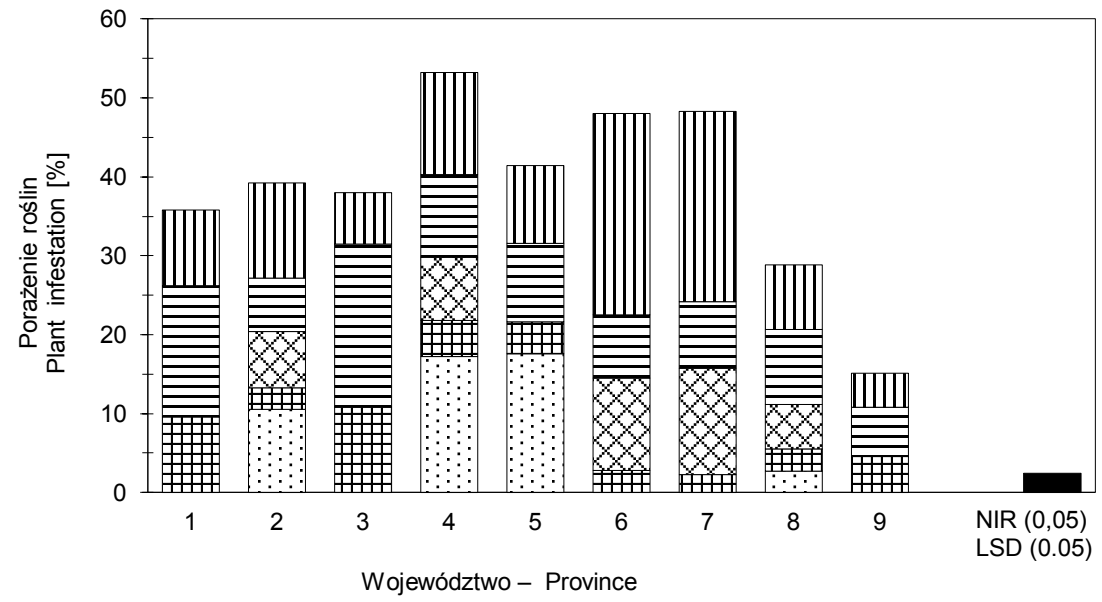

$$
\begin{aligned}
& 1 \text { - kujawsko-pomorskie, } 2 \text { - lubelskie, } 3 \text { - mazowieckie, } 4 \text { - podkarpackie, } 5 \text { - podlaskie, } \\
& 6 \text { - pomorskie, } 7 \text { - warmińsko-mazurskie, } 8 \text { - wielkopolskie, } 9 \text {-zachodniopomorskie } \\
& \text { (1) Sclerotinia } \\
& \text { - Fusarium ssp. } \quad \text { Fusarium } \\
& \text { oxysporum } \\
& \text { Q Pleospora } \\
& \text { herbarum }
\end{aligned}
$$

Rys. 3. Porażenie roślin łubınu przez patogeny w zależności od rejonu Polski

Fig. 3. Infection of lupine plants by fungal pathogens in dependence on region of Poland

Występowanie chorób grzybowych związane było przede wszystkim z korzys tnym dla ich rozwoju przebiegiem warunków pogodowych: dla antraknozy - wysoka temperatura i duża ilość opadów, zwłaszcza w okresie kwitnienia, a dla fuzaryjnego więdnięcia łubinu i zgorzeli siewek - nadmierna wilgotność i niska temperatura lub mała wilgotność i wysoka temperatura, co potwierdzają wyniki badań Sowy i Sadowskiego (1979), Frencel (1999) oraz Zalewskiego i wsp. (2003).

Stwierdzono znaczną różnicę $\mathrm{w}$ podatności badanych odmian łubinu na poszczególne grzyby chorobotwórcze (tab. 2). W odniesieniu do antraknozy największą odporność na tę chorobę odnotowano dla odmian: Regent, Sonet i Graf, a najmniejszą dla odmian: Baron, Zeus i Tango. Również z badań Frencel (2000) wynika, że występują duże różnice między odmianami w zakresie ich podatności na porażenie przez C. gloeosporioides, chociaż dotyczą one starszych odmian łubinu. Chorobą występującą w małym nasileniu była opadzina liści powodowana przez $P$. herbarum. Nieco większe porażenie roślin stwierdzono w przypadku odmian Sonet i Mirela, a mniejsze w odniesieniu do odmian Graf i Regent. Odmiany Boruta, Dalbor, Kadryl i Zeus były najbardziej porażane przez $F$. oxysporum, a odmiany Kalif, Oskar, Sonet i Tango najmniej. Z kolei najmniej podatne na zgorzel siewek były odmiany Graf, Oskar i Tango, a na zgniliznę twardzikową odmiany - Graf, Kadryl i Mirela.

Plonowanie łubinu wąskolistnego było zróżnicowane $\mathrm{w}$ większym stopniu $\mathrm{w}$ zależności od rejonu uprawy niż odmiany (tab. 3). Średnio z 3 lat badań najwyższy plon nasion tubinu uzyskano $\mathrm{w}$ województwie zachodniopomorskim (4,0 t/ha), a najniższy w województwie pod- 
Tabela 2. Porażenie roślin tubinu wąskolistnego przez patogeny w latach 2010-2012 [\%]

Table 2. Infection of blue lupine cultivars by pathogens (2010-2012) [\%]

\begin{tabular}{|c|c|c|c|c|c|}
\hline \multirow[b]{2}{*}{$\begin{array}{l}\text { Odmiana } \\
\text { Cultivar }\end{array}$} & \multicolumn{5}{|c|}{ Choroba/Patogen - Disease/Pathogen } \\
\hline & $\begin{array}{c}\text { antraknoza } \\
\text { Colletotrichum ssp. }\end{array}$ & $\begin{array}{c}\text { opadzina liści } \\
\text { Pleospora } \\
\text { herbarum }\end{array}$ & $\begin{array}{c}\text { fuzaryjne } \\
\text { więdnięcie łubinu } \\
\text { Fusarium oxysporum }\end{array}$ & $\begin{array}{c}\text { zgorzel } \\
\text { siewek } \\
\text { Fusarium ssp. }\end{array}$ & $\begin{array}{c}\text { zgnilizna } \\
\text { twardzikowa } \\
\text { Sclerotinia } \\
\text { sclerotiorum }\end{array}$ \\
\hline Baron & 9,3 & 4,4 & 4,4 & 6,1 & 8,9 \\
\hline Bojar & 5,8 & 3,3 & 4,4 & 9,4 & 11,7 \\
\hline Boruta & 6,8 & 3,2 & 10,3 & 10,6 & 13,9 \\
\hline Dalbor & 4,4 & 5,6 & 11,6 & 12,8 & 15,0 \\
\hline Graf & 1,1 & 1,2 & 4,4 & 5,0 & 1,7 \\
\hline Heros & 4,8 & 5,6 & 4,4 & 13,9 & 28,3 \\
\hline Kadryl & 4,1 & 3,3 & 11,4 & 10,6 & 3,3 \\
\hline Kalif & 3,1 & 4,2 & 1,1 & 9,4 & 12,8 \\
\hline Karo & 5,3 & 4,4 & 5,6 & 12,8 & 22,8 \\
\hline Mirela & 3,6 & 8,9 & 2,2 & 19,4 & 0,6 \\
\hline Neptun & 5,9 & 6,7 & 3,3 & 13,9 & 17,2 \\
\hline Regent & 1,0 & 1,2 & 3,1 & 12,8 & 13,9 \\
\hline Sonet & 2,0 & 7,8 & 1,1 & 20,6 & 16,1 \\
\hline Zeus & 10,4 & 5,4 & 12,2 & 11,7 & 9,4 \\
\hline Oskar & 6,9 & 5,7 & 0,0 & 2,8 & 13,9 \\
\hline Tango & 9,4 & 5,7 & 1,1 & 0,6 & 11,7 \\
\hline Średnio - Mean & 5,3 & 4,8 & 4,9 & 10,8 & 12,6 \\
\hline $\operatorname{NIR}(0,05)-\operatorname{LSD}(0.05)$ & 3,24 & 1,86 & 2,64 & 4,78 & 3,45 \\
\hline
\end{tabular}

Tabela 3. Plonowanie łubinu wąskolistnego w latach 2010-2012 [dt/ha]

Table 3. Yield of blue lupine in the years 2010-2012 [dt/ha]

\begin{tabular}{|c|c|c|c|c|c|c|c|c|c|c|c|}
\hline \multirow{2}{*}{$\begin{array}{l}\text { Odmiana } \\
\text { Cultivar }\end{array}$} & \multicolumn{9}{|c|}{ Województwo - Province* } & \multirow{2}{*}{$\begin{array}{l}\text { Średnio } \\
\text { Mean }\end{array}$} & \multirow{2}{*}{$\begin{array}{l}\text { NIR }(0,05) \\
\operatorname{LSD}(0.05)\end{array}$} \\
\hline & 1 & 2 & 3 & 4 & 5 & 6 & 7 & 8 & 9 & & \\
\hline Baron & 3,2 & 2,9 & 3,7 & 2,3 & 2,4 & 2,7 & 3,0 & 3,0 & 3,9 & 3,0 & 0,46 \\
\hline Bojar & 4,2 & 2,6 & 3,6 & 2,2 & 1,8 & 2,9 & 3,0 & 2,9 & 4,3 & 3,0 & 0,35 \\
\hline Boruta & 4,4 & 2,7 & 3,6 & 1,9 & 1,9 & 3,0 & 3,1 & 2,7 & 3,9 & 3,0 & 0,72 \\
\hline Dalbor & 4,6 & 2,7 & 3,7 & 2,0 & 2,4 & 3,2 & 2,6 & 3,3 & 4,2 & 3,2 & 0,58 \\
\hline Graf & 4,0 & 2,5 & 3,7 & 1,9 & 2,2 & 3,1 & 2,9 & 2,8 & 4,1 & 3,0 & 0,77 \\
\hline Heros & 4,3 & 2,9 & 3,7 & 1,9 & 2,6 & 3,1 & 2,6 & 3,2 & 4,2 & 3,2 & 0,41 \\
\hline Kadryl & 2,9 & 2,6 & 3,4 & 2,1 & 2,0 & 2,8 & 2,9 & 2,7 & 3,9 & 2,8 & 0,53 \\
\hline Kalif & 4,3 & 2,8 & 3,6 & 1,9 & 2,3 & 3,1 & 3,3 & 2,9 & 4,0 & 3,1 & 0,67 \\
\hline Karo & 2,9 & 2,6 & 3,7 & 2,2 & 2,1 & 3,0 & 3,4 & 3,0 & 4,0 & 3,0 & 0,55 \\
\hline Mirela & 3,0 & 2,7 & 3,9 & 2,4 & 1,8 & 2,1 & 3,0 & 1,9 & 3,8 & 2,7 & 0,53 \\
\hline Neptun & 2,7 & 2,7 & 3,7 & 2,0 & 2,2 & 2,9 & 3,2 & 2,9 & 4,1 & 2,9 & 0,71 \\
\hline Oskar & 4,1 & 2,8 & 3,4 & 0,7 & 2,1 & 3,4 & 2,4 & 2,7 & 3,2 & 2,8 & 0,86 \\
\hline Regent & 2,9 & 2,6 & 3,6 & 2,5 & 2,0 & 3,0 & 2,7 & 2,6 & 4,1 & 2,9 & 0,81 \\
\hline Sonet & 2,2 & 2,2 & 3,5 & 1,8 & 1,7 & 2,6 & 2,8 & 2,4 & 3,8 & 2,6 & 0,94 \\
\hline Tango & 4,3 & 2,4 & 3,1 & 0,9 & 2,7 & 3,1 & 3,9 & 3,5 & 4,3 & 3,1 & 0,69 \\
\hline Zeus & 3,6 & 2,5 & 3,7 & 2,4 & 2,1 & 3,2 & 3,0 & 2,8 & 3,9 & 3,0 & 0,78 \\
\hline Średnio - Mean & 3,6 & 2,6 & 3,6 & 1,9 & 2,1 & 2,9 & 3,0 & 2,8 & 4,0 & 3,0 & 0,85 \\
\hline $\operatorname{NIR}(0,05)-\operatorname{LSD}(0.05)$ & 0,46 & r.n. & 0,43 & 0,21 & 0,34 & 0,48 & 0,30 & 0,58 & r.n. & 0,43 & - \\
\hline
\end{tabular}

*1 - kujawsko-pomorskie, 2 - lubelskie, 3 - mazowieckie, 4 - podkarpackie, 5 - podlaskie, 6 - pomorskie, 7 - warmińsko-mazurskie, 8 - wielkopolskie, 9 - zachodniopomorskie

r.n. - różnica nieistotna - not significant difference 
Tabela 4. Masa 1000 nasion łubinu wąskolistnego w latach (2010-2012) [g]

Table 4. Weight of 1000 seeds of blue lupine in the years 2010-2012 [g]

\begin{tabular}{|c|c|c|c|c|c|c|c|c|c|c|c|}
\hline \multirow{2}{*}{$\begin{array}{l}\text { Odmiana } \\
\text { Cultivar }\end{array}$} & \multicolumn{9}{|c|}{ Województwo - Province* } & \multirow{2}{*}{$\begin{array}{c}\text { Średnio } \\
\text { Mean }\end{array}$} & \multirow{2}{*}{$\begin{array}{l}\operatorname{NIR}(0,05) \\
\operatorname{LSD}(0.05)\end{array}$} \\
\hline & 1 & 2 & 3 & 4 & 5 & 6 & 7 & 8 & 9 & & \\
\hline Baron & 137 & 137 & 141 & 143 & 138 & 142 & 138 & 146 & 130 & 139 & r.n. \\
\hline Bojar & 153 & 161 & 163 & 166 & 144 & 159 & 154 & 165 & 153 & 158 & r.n. \\
\hline Boruta & 137 & 135 & 152 & 144 & 128 & 148 & 132 & 152 & 150 & 142 & 7,12 \\
\hline Dalbor & 126 & 148 & 135 & 131 & 129 & 140 & 130 & 147 & 142 & 136 & r.n. \\
\hline Graf & 123 & 134 & 133 & 130 & 125 & 133 & 133 & 145 & 121 & 131 & 9,24 \\
\hline Heros & 115 & 129 & 123 & 123 & 117 & 128 & 118 & 136 & 132 & 124 & 8,64 \\
\hline Kadryl & 142 & 152 & 154 & 154 & 143 & 148 & 148 & 152 & 147 & 149 & r.n. \\
\hline Kalif & 135 & 134 & 149 & 146 & 144 & 157 & 146 & 149 & 137 & 144 & r.n. \\
\hline Karo & 165 & 170 & 187 & 176 & 156 & 174 & 167 & 180 & 182 & 173 & 10,31 \\
\hline Mirela & 134 & 156 & 156 & 155 & 127 & 142 & 137 & 150 & 140 & 144 & 12,25 \\
\hline Neptun & 160 & 150 & 159 & 155 & 144 & 157 & 142 & 152 & 155 & 153 & r.n. \\
\hline Oskar & 131 & 132 & 140 & 137 & 128 & 149 & 129 & 150 & 148 & 138 & 7,11 \\
\hline Regent & 146 & 91 & 167 & 139 & 138 & 158 & 144 & 154 & 163 & 144 & 14,28 \\
\hline Sonet & 143 & 148 & 149 & 150 & 134 & 152 & 146 & 147 & 142 & 146 & r.n. \\
\hline Tango & 123 & 120 & 129 & 104 & 133 & 121 & 126 & 159 & 132 & 127 & 7,14 \\
\hline Zeus & 157 & 160 & 151 & 128 & 163 & 150 & 157 & 149 & 149 & 152 & 5,68 \\
\hline Średnio - Mean & 139 & 141 & 149 & 143 & 137 & 147 & 140 & 152 & 145 & 144 & 7,56 \\
\hline $\operatorname{NIR}(0,05)-\operatorname{LSD}(0.05)$ & 9,32 & 12,14 & 8,26 & 7,18 & 6,72 & 7,21 & 8,43 & 9,89 & 11,41 & 10,14 & - \\
\hline
\end{tabular}

*1 - kujawsko-pomorskie, 2 - lubelskie, 3 - mazowieckie, 4 - podkarpackie, 5 - podlaskie, 6 - pomorskie, 7 - warmińsko-mazurskie, 8 - wielkopolskie, 9 - zachodniopomorskie

r.n. - różnica nieistotna - not significant difference

karpackim (1,9 t/ha). Stwierdzono wyraźną zależność między porażeniem roślin przez grzyby chorobotwórcze a ich plonowaniem. Spośród analizowanych chorób największy wpływ na poziom plonowania łubinu miała antraknoza. Najwyższy plon nasion uzyskano z rejonów uprawy, gdzie nie stwierdzono występowania antraknozy (np. województwo zachodniopomorskie), a najniższy w rejonach o dużym nasileniu tej choroby (województwa: lubelskie, podkarpackie, podlaskie i wielkopolskie). Redukcja plonu średnio dla tych województw w porównaniu do województw, gdzie antraknoza nie występowała wynosiła około 30\%. Również duży wpływ na plonowanie łubinu miało występowanie fuzaryjnego więdnięcia łubinu powodowanego przez $F$. oxysporum (zniżka plonu w stosunku do województw, gdzie choroba ta nie występowała wynosiła około 20\%). Potwierdza to dużą szkodliwość tej choroby w uprawie łubinu i uzasadnia potrzebę podejmowania działań zmierzających do jej ograniczenia (Lewartowska i wsp. 1994; Jańczak i wsp. 2003; Jędryczka i Kaczmarek 2012).

Szkodliwość chorób łubinu nie ogranicza się jednak tylko do obniżki plonu nasion, bowiem $\mathrm{z}$ doniesień literatury wynika, że mogą one powodować także pogorszenie jakości plonu nasion łubinu (Horoszkiewicz i Filoda 2001). Dlatego zaleca się ich zwalczanie, stosując odpowiednią ochronę chemiczną. Jednak obecnie zarejestrowanych jest bardzo mało fungicydów do zwalczania chorób łubinu wąskolistnego, co stanowi duży problem w uprawie tego gatunku.
Średnio dla 3 lat badań i wszystkich miejscowości, plon nasion uwzględnionych w badaniach odmian łubinu kształtował się w granicach 2,6-3,2 t/ha. Najlepiej, niezależnie od rejonu uprawy, plonował łubin odmiany Dalbor i Heros, a najsłabiej łubin odmiany Sonet.

Uwzględnione w badaniach odmiany łubinu charakteryzowały się zróżnicowaną masą 1000 nasion (średnio dla wszystkich miejscowości od 124 do 173 g). Duży wpływ na wielkość tej cechy miał także rejon uprawy (tab. 4). Średnio dla wszystkich odmian nasiona o najwyższej MTN uzyskano w województwie wielkopolskim (152 g), a o najmniejszej MTN w województwie podlaskim (137 g). Cecha ta nie była dodatnio skorelowana $\mathrm{z}$ plonem nasion, chociaż uważana jest obok liczby strąków na roślinie za jeden $\mathrm{z}$ elementów decydujących o poziomie plonowania łubinu wąskolistnego (Podleśny i Strobel 2006; Podleśny i Podleśna 2010; Barczak i wsp. 2013).

\section{Wnioski / Conclusions}

1. Stwierdzono zróżnicowane porażenie roślin łubinu wąskolistnego przez patogeny w poszczególnych rejonach Polski. W największym nasileniu występowały choroby uznawane za mniej groźne w uprawie łubinu wąskolistnego: zgorzel siewek i zgnilizna twardzikowa. Choroby szczególnie niebezpieczne, takie jak fuzaryjne więdnięcie łubinu, a zwłaszcza antraknoza występowały tylko w niektórych rejonach kraju. 
2. Wystąpiła wyraźna zależność między rozwojem chorób a przebiegiem warunków pogodowych. Zwiększone nasilenie antraknozy obserwowano w rejonach Polski z dużą ilością opadów i wysoką temperaturą w okresie kwitnienia łubinu, a występowanie fuzaryjnego więdnięcia łubinu - w warunkach małej ilości opadów i wysokiej temperatury.

3. Stwierdzono znaczną różnicę $\mathrm{w}$ podatności odmian łubinu na poszczególne patogeny. Większą odpornością na najgroźniejszą chorobę łubinów - antraknozę wyróżniały się odmiany Regent, Sonet i Graf, a znacznie mniejszą odmiany Baron, Zeus i Tango.

4. Zróżnicowanie w wielkości plonów nasion łubinu wąskolistnego w większym stopniu wynikało $\mathrm{z}$ rejonu uprawy niż odmiany. Średnio z 3 lat badań najwyższy plon nasion łubinu uzyskano $\mathrm{w}$ województwie zachod- niopomorskim, a najniższy w województwie podkarpackim.

5. Stwierdzono wyraźną zależność między porażeniem roślin przez patogeny a ich plonowaniem. Spośród analizowanych chorób największy wpływ na poziom plonowania łubinu miała antraknoza i fuzaryjne więdnięcie łubinu.

Praca wykonana w ramach realizacji zadania 3.3 w Programie Wieloletnim Instytutu Uprawy Nawożenia i Gleboznawstwa - Państwowego Instytutu Badawczego w Puławach pt. „Wspieranie działań w zakresie kształtowania środowiska rolniczego i zrównoważonego rozwoju produkcji rolniczej w Polsce".

\section{Literatura / References}

Barczak B., Nowak K., Knapowski T., Ralcewicz M., Kozera W. 2013. Reakcja łubinu wąskolistnego (Lupinus angustifolius L.) na nawożenie siarką. Cz. I. Plon oraz wybrane elementy jego struktury. Fragmenta Agronomica 30 (2): 23-34.

Buraczyńska D., Ceglarek F. 2008. Plonowanie pszenicy ozimej uprawianej po różnych przedplonach. Acta Scientiarum Polonorum, Agricultura 7 (1): 27-37.

Filoda G., Horoszkiewicz J., Jańczak C. 2001. Występowanie i szkodliwość antraknozy na łubinie żółtym w różnych warunkach pogodowych 1999 i 2000 roku. [Occurence and pathogenity of yellow lupin anthracnose in different weather conditions in 1999 and 2000]. Progress in Plant Protection/Postępy w Ochronie Roślin 41 (1): 278-285.

Frencel I. 1999. Postępy badań nad antraknozą łubinów (Glomerella cingulata/Colletotrichum gloeosporioides) w Polsce i Europie. s. 199-206. W: Materiały Konferencyjne „Lupin in Polish and European Agriculture”. Polskie Towarzystwo Łubinowe. Przysiek, 2-3 wrzesień 1999, 207 ss.

Frencel I. 2000. Kierunki i perspektywy hodowli odpornościowej łubinów na antraknozę w świetle aktualnych badań. s. $20-31$. W: Materiały Konferencyjne „Obecny stan i kierunki badań nad łubinem w Polsce ze szczególnym uwzględnieniem antraknozy”. Instytut Ochrony Roślin. Poznań, 12 styczeń 2000, 48 ss.

Horoszkiewicz J., Filoda G. 2001. Choroby grzybowe łubinu żółtego i wąskolistnego. Zeszyty Naukowe Akademii Rolniczej we Wrocławiu, Rolnictwo 427: 185-193.

Horoszkiewicz-Janka J., Korbas M., Jajor E., Krawczyk R. 2011. Health of narrow-leaved lupin (Lupinus angustifolius L.) cultivated in the conventional farming system and in transition period to the ecological system. Journal of Research and Applications in Agricultural Engineering 55 (3): 143-146.

Jańczak C., Filoda G., Horoszkiewicz-Janka J. 2003. Antraknoza łubinu w Polsce w latach 1999-2002, zwalczanie i skuteczność działania środków grzybobójczych. Zeszyty Problemowe Postępów Nauk Rolniczych 195: 251-260.

Jańczak C., Horoszkiewicz J., Filoda G., Czerwińska A. 2001. Choroby grzybowe łubinu wąskolistnego i ich zwalczanie. [Fungal diseases of narrow-leafed lupin and their control]. Progress in Plant Protection/Postępy w Ochronie Roślin 41 (2): 714-717.

Jerzak M.A. 2014. Możliwości restytucji rynku rodzimych roślin strączkowych na cele paszowe w Polsce. Roczniki Naukowe XVI, 3: 104-109.

Jędryczka M., Kaczmarek J. 2012. Porażenie nasion łubinu wąskolistnego znajdujących się w obrocie komercyjnym przez grzyby chorobotwórcze i saprotroficzne. Fragmenta Agronomica 29 (4): 63-69.

Kalembasa S., Wysokiński A., Kalembasa D. 2014. Quantitative assessment of the process of biological nitrogen reduction by yellow lupine (Lupinus luteus L.). Acta Scientiarum Polonorum, Agricultura 13 (1): 5-20.

Kopiński J., Matyka M. 2012. Regionalne zróżnicowanie produkcji i opłacalności upraw roślin strączkowych pastewnych na nasiona w Polsce. Polish Journal of Agronomy 10: 9-15.

Kurowski T.P., Cwalina-Ambroziak B., Sadowski T. 2001. Choroby czterech odmian łubinu żółtego uprawianego w zróżnicowanych płodozmianach. Zeszyty Naukowe Akademii Rolniczej we Wrocławiu, Rolnictwo 82: 205-213.

Kurowski T.P., Jaźwińska E. 2010. Wpływ inokulacji zarodnikami Colletotrichum lupini (Bondar) Nirenberg, Feilert, Hagedorn na stopień porażenia roślin $\mathrm{w}$ okresie wegetacji oraz występowanie patogena na nasionach czterech gatunków łubinu. Zeszyty Problemowe Postępów Nauk Rolniczych 550: 131-138.

Lewartowska E., Jędryczka M., Frencel I., Pieczyrak J. 1994. Seed-borne fungi of Lupinus angustifolius L. cultivars. Phytopathologia Polonica 7: 123-130.

Morkunas I., Narożna D., Nowak W., Samardakiewicz W., Remlein-Starosta D. 2011. Cross-talk interactions of sucrose and Fusarium oxysporum in the phenylpropanoid pathway and the accumulation and localization of flavonoids in embryo axes of yellow lupine. Journal of Plant Physiology 168: 424-433.

Podleśny J., Brzóska F. 2010. Uprawa łubinu wąskolistnego i wykorzystanie nasion w żywieniu zwierząt. Instrukcja Upowszechnieniowa. Instytut Uprawy Nawożenia i Gleboznawstwa - Państwowy Instytut Badawczy, Puławy, 34 ss.

Podleśny J., Podleśna A. 2010. Wpływ temperatury w początkowym okresie wzrostu na plonowanie termo- i nietermoneutralnych odmian łubinu wąskolistnego. Zeszyty Problemowe Postępów Nauk Rolniczych 550: 97-104.

Podleśna A., Podleśny J., Doroszewski A. 2014. Usefulness of selected weather indices to evaluation of yellow lupine yielding possibility. Agricultural Water Management 146: 201-207. 
Podleśny J., Strobel W. 2006. Wpływ terminu siewu na kształtowanie wielkości plonu nasion i białka zróżnicowanych genotypów hubinu wąskolistnego. Acta Agrophysica 142, 8 (4): 923-933.

Prusiński J. 2010. Rośliny strączkowe w Unii Europejskiej. Zeszyty Problemowe Postępów Nauk Rolniczych 550: 11-19.

Prusiński J., Kaszkowiak E., Borowska M. 2008. Wpływ nawożenia i dokarmiania roślin azotem na plonowanie i strukturalne elementy plonu nasion bobiku. Fragmenta Agronomica 25 (4): 111-127.

Sowa A., Sadowski Cz. 1979. Występowanie zgorzeli korzeni grochu (Pisum sativum L.) na plantacjach w województwie bydgoskim. Zeszyty Naukowe Akademii Techniczno-Rolniczej w Bydgoszczy 76 (8): 49-63.

Szukała J. 2012. Nowe trendy w agrotechnice roślin strączkowych i sposoby zwiększania opłacalności uprawy. Materiały Komisji Rolnictwa i Rozwoju Wsi, Warszawa, 45: 8-10.

Thomas G.J., Sweetingham M.W. 2004. Cultivar and environment influence the development of lupin anthracnose caused by Colletotrichum lupine. Australasian Plant Pathology 33: 571-577.

Wenda-Piesik A., Breza-Boruta B. 2008. Wpływ wilgotności gleby i zaprawiania nasion na porażenie grochu siewnego przez Fusarium solani F. sp. pisi i Fusarium oxysporum F. sp. pisi oraz wzrost roślin. [Effect of soil moisture and seed dressing on pea growth and infestation by Fusarium solani F. sp. pisi and Fusarium oxysporum F. sp. pisi]. Progress in Plant Protection/Postępy w Ochronie Roślin 48 (3): 1130-1135.

Zalewski D., Janiszewska I., Janiszewska K., Kotowicz Z., Wójcik B., Śmiałek E. 2003. Ocena podatności odmian łubinu żółtego (Lupinus luteus L.) na Fusarium spp. w zależności od warunków klimatyczno-glebowych. Zeszyty Problemowe Postępów Nauk Rolniczych 495: 307-314. 